\title{
ANALISIS FAKTOR-FAKTOR PEMANFAATAN SISTEM INFORMASI MANAJEMEN RUMAH SAKIT DI RUMAH SAKIT UMUM SEMBIRING KABUPATEN DELI SERDANG TAHUN 2020
}

\author{
Akhmad Fatikhus Sholikh, Ripai Siregar, Rizka Annisa \\ Institut Kesehatan Deli Husada \\ e-mail : fatihsholih.fs@gmail.com
}

\begin{abstract}
Hospitals are required to have a SIMRS that functions according to Law of the Republic of Indonesia Number 44 of 2009 concerning raft houses. However, based on data from the Ministry of Health in 2019 out of 2,761 hospitals in Indonesia, only 1,564 hospitals (56\%) use SIMRS and function. The purpose of this study was to analyze the factors associated with the use of SIMRS in Sembiring General Hospital using a cross sectional research design. Total population of 258 people, with a total sample of 72 health workers using a proportional stratified random sampling method. The research instrument is a questionnaire. Data analysis methods are univariate, bivariate with chi square test and multivariate with multiple linear regression tests. The results showed that of 72 health workers as many as 47 people (65\%) stated that the use of SIMRS was in the good category and 35 people (35\%) stated that the utilization of SIMRS was in the poor category. The results of the bivariate analysis address effort expectations, performance expectations, social influence and facilitating conditions related to the use of SIMRS with a value of $p<0.05$. The results of multivariate analysis showed that efforts expectations were the factors most related to the use of SIMRS with a coefficient value (0.012). It is recommended that hospitals provide SIMRS that is easy to operate, in order to improve the performance of health workers with the influence of a good social environment and the conditions of the supporting facilities.
\end{abstract}

Keywords : Utilization of SIMRS, Effort Expectations, Performance expectations, Social Influence, and Facilitating Conditions

\section{PENDAHULUAN}

Menurut Undang-Undang RI Nomor 44 Tahun 2009 tentang rumah sakit, Rumah Sakit harus memberikan informasi yang benar tentang pelayanan Rumah Sakit kepada masyarakat yang meliputi Informasi umum tentang Rumah Sakit dan informasi yang berkaitan dengan pelayanan medis kepada Pasien.

Dalam hal ini tentunya tenaga kesehatan membutuhkan suatu teknologi dan sistem informasi yang dapat dimanfaatakan dalam melaksanakan kewajibannya. Salah satu bentuk penerapannya melalui 
pelayanan dengan memanfaatkan teknologi informasi. Rumah Sakit harus melaksanakan semua kegiatan pencatatan dan pelaporan semua kegiatan Rumah Sakit, sebagaimana yang terdapat dalam Undang-Undang Nomor 44 tahun 2009 tentang Rumah Sakit. Kegiatan pencatatan dan pelaporan tersebut dilakukan dalam bentuk Sistem Informasi Manajemen Rumah Sakit (SIMRS). Berdasarkan Peraturan Menteri Kesehatan RI Nomor 82 tahun 2013 tentang Sistem Informasi Manajemen Rumah Sakit. Sistem informasi manajemen Rumah Sakit (SIMRS) yang digunakan di sebuah Rumah Sakit harus memberikan kemudahan dalam operasional serta harus dapat mengatasi kendala pelayanan pasien yang ada di Rumah Sakit tersebut.

Pemerintah menargetkan seluruh Rumah Sakit di Indonesia harus sudah mempunyai SIMRS yang terintegrasi pada tahun 2018. Namun Berdasarkan data yang diperoleh dari bagian program dan informasi Kementerian Kesehatan tahun 2019 hanya sekitar 1.564 rumah sakit (56\%) yang mempunyai SIMRS dan berjalan sesuai fungsinya.

Rumah Sakit Umum Sembiring adalah Rumah Sakit tipe B yang terletak di Kecamatan Deli Tua Kabupaten Deli Serdang Provinsi Sumatera Utara, yang sudah menerapkan SIMRS \pm 4 tahun sejak tahun 2015 yang terhubung dengan jaringan (Local Area Network), yaitu penghubung antar unit pelayanan rumah sakit, namun belum secara keseluruhan sudah terintegrasi dengan SIMRS dari masing-masing unit pelayanan di Rumah Sakit.

Berdasarkan hasil wawancara dengan bagian SDM Rumah Sakit umum menargetkan tahun 2020 semua unit pelayanan akan terintegrasi dengan SIMRS, namun masih terkendala dari SDM dari masing-masing unit yang harus mengikuti pelatihan kembali tentang pemanfaatan SIMRS untuk mencapai target tersebut.

Berdasarkan hasil observasi awal di unit rekam medis, ada keluhan dari pengguna tentang SIMRS yang saat ini sedang berjalan. Fitur -fitur SIMRS yang ada di Rumah Sakit Umum Sembiring belum terintegrasi dengan pelaporan SIRS online yang ada di Badan Upaya Kesehatan (BUK) Kemenkes RI. terjadi adalah pengerjaan laporan Rumah Sakit yang lama, karena kecepatan dan akurasi data menurun sehingga waktu yang dibutuhkan untuk melakukan pekerjaan-pekerjaan administrasi untuk pelaporan melalui SIRS online ke Badan Upaya Kesehatan (BUK) Kemenkes RI malah bertambah banyak dan bisa mengalami keterlambatan dalam pelaporan yang akan mengakibatkan rumah sakit bisa dianggap tidak tertib dari segi administrasi pelaporan ke Kementrian Kesehatan.

Hasil survey awal yang dilakukan di unit rekam medis dan SIRS pada 24 Orang yang memanfaatkan informasi dari SIMRS, menunjukan 10 Orang (40\%) menyatakan cukup baik dan 14 orang $(60 \%)$ menyatakan baik dalam penerapan SIMRS yang sudah berjalan di Rumah Sakit Umum Sembiring.

Oleh karena itu perlu
diperhatikan beberapa faktor yang
berhubungan dengan minat tenaga
kesehatan dalam memanfaatkan


SIMRS, seperti ekspektasi kinerja yang artinya seberapa tinggi seorang percaya bahwa menggunakan suatu sistem akan membantu mendapatkan suatu keuntungan dalam kinerjanya, ekspektasi usaha yang diartikan sebagai tingkat kemudahan dalam menggunakan suatu sistem, selain itu harus didukung dengan lingkungan sosial harus mendukung dalam pemanfaatan suatu sistem, dan kondisi fasilitas dari suatu sistem harus mendukung dalam penggunaan SIMRS itu sendiri.

Dalam pemanfaatan SIMRS Ternyata masih terdapat masalah. Maka dari itu perlu dilakukan penelitian lebih lanjut mengenai faktor-faktor yang berhubungan dengan pemanfaatan Sistem Informasi Manajemen Rumah Sakit Umum Sembiring Kabupaten Deli Serdang.

\section{METODE PENELITIAN}

Penelitian ini mempergunakan metode deskriptif analitik untuk menggambarkan serta menganalisa faktor- faktor yang berhubungan dengan pemanfaatan sistem informasi manajemen rumah sakit umum Sembiring Deli Tua. Rancangan penelitian ini adalah cross sectional.

Populasi dalam penelitian adalah tenaga kesehatan yang menjadi jangkauan dari sistem informasi manajemen rumah sakit umum Sembiring dari masing-masing instalasi yang berjumlah 258 Orang. Dengan menggunakan teknik pengambilan sampel yaitu proportional stratified random sampling. Dalam menghitung jumlah sampel minimum dalam penelitian ini menggunakan rumus slovin. Jumlah sampel yang diperoleh adalah 72
Orang tenaga kesehatan yang memanfaatkan SIMRS.

\section{HASIL DAN PEMBAHASAN} Analisa Univariat

Tabel 1. Distribusi Frekuensi

Karakteristik Responden Berdasarkan Umur

\begin{tabular}{|c|c|c|c|}
\hline No & Umur & Frekuensi & Persentase (\%) \\
\hline 1 & 17-31 Tahun & 25 & 34 \\
\hline 2 & 32-46 Tahun & 37 & 52 \\
\hline 3 & 40-60 Tahun & 10 & 14 \\
\hline & Total & 72 & 100 \\
\hline
\end{tabular}

Berdasarkan di atas diketahui bahwa dari 72 tenaga kesehatan distribusi berdasarkan umur $17-31$ Tahun sebanyak 25 Orang (34\%), 3246 tahun sebanyak 37 orang (52\%) dan 40-60 tahun sebanyak 10 Orang (14\%).

Tabel 2. Distribusi Frekuensi Karakteristik Responden Berdasarkan Jenis Kelamin

\begin{tabular}{rccc}
\hline No & Jenis Kelamin & Frekuensi & Persentase (\%) \\
& & & \\
\hline 1 & Laki-laki & 23 & 32 \\
2 & Perempuan & 49 & 68 \\
\hline \multicolumn{5}{r}{ Total } & 72 & 100 \\
\hline
\end{tabular}

Berdasarkan Tabel di atas diketahui bahwa dari 72 tenaga kesehatan distribusi berdasarkan Jenis kelamin laki-laki sebanyak 23 Orang $(32 \%)$, dan perempuan 49 Orang $(68 \%)$.

Tabel 3. Distribusi Frekuensi Karakteristik Responden Berdasarkan Masa Kerja

\begin{tabular}{|c|c|c|c|}
\hline No & Masa Kerja & Frekuensi & Persentase $(\%)$ \\
\hline 1 & <1Tahun & 21 & 29 \\
\hline 2 & 1-2 Tahun & 37 & 51 \\
\hline 3 & $>$ 3Tahun & 14 & 20 \\
\hline & Total & 72 & 100 \\
\hline
\end{tabular}


Berdasarkan tabel diatas diketahui bahwa dari 72 tenaga kesehatan distribusi berdasarkan masa kerja kurang dari 1 tahun ada 21 Orang (29\%), 1-2 tahun ada 37 Orang $(51 \%)$ dan lebih dari 3 tahun ada 14 Orang (20\%).

Tabel 4. Distribusi Frekuensi Karakteristik Responden Berdasarkan tingkat Pendidikan

\begin{tabular}{rccc}
\hline No & Tingkat pendidikan & Frekuensi & Persentase (\%) \\
\hline 1 & Diploma 3 & 37 & 51 \\
2 & Sarjana & 13 & 18 \\
3 & Profesi & 16 & 22 \\
4 & Magister/Spesialis & 6 & 9 \\
\hline & Total & 72 & 100 \\
\hline
\end{tabular}

Berdasarkan table di atas diketahui bahwa dari 72 tenaga kesehatan distribusi berdasarkan tingkat pendidikan Diploma 351 orang (37\%), sarjana 13 Orang $(18 \%)$, profesi 16 Orang (22\%), dan magister ataupun spesialis 6 Orang (9\%).

Tabel 5. Distribusi Frekuensi Data Univariat Responden Berdasarkan Ekspektasi Usaha

\begin{tabular}{ccc}
\hline Ekspektasi Usaha & Frekuensi & Persentase $(\%)$ \\
\hline Kurang & 25 & 35 \\
& & \\
Baik & 47 & 65 \\
\hline Total & 72 & 100 \\
\hline
\end{tabular}

Berdasarkan tabel di atas diketahui bahwa dari 72 orang tenaga kesehatan 25 Orang (35\%) menyatakan ekspektasi usaha dalam menggunakan SIMRS kurang baik dan 47 Orang (65\%) menyatakan ekspektasi baik dalam menggunakan SIMRS.
Tabel 6. Distribusi Frekuensi Data Univariat Responden Berdasarkan Ekspektasi Kinerja

\begin{tabular}{ccc}
\hline Ekspektasi kinerja & Frekuensi & Persentase (\%) \\
\hline Kurang & 26 & 36 \\
Baik & 46 & 64 \\
\hline Total & 72 & 100 \\
\hline
\end{tabular}

Berdasarkan tabel di atas diketahui bahwa dari 72 orang tenaga kesehatan 26 Orang (36\%) menyatakan ekspektasi kinerja dalam menggunakan SIMRS kurang baik dan 46 Orang (64\%) menyatakan ekspektasi kinerja baik dalam menggunakan SIMRS.

Tabel 7. Distribusi Frekuensi Data Univariat Responden berdasarkan Pengaruh Sosial

\begin{tabular}{ccc}
\hline Pengaruh sosial & Frekuensi & Persentase (\%) \\
\hline Kurang baik & 24 & 40 \\
Baik & 48 & 60 \\
\hline Total & 72 & 100 \\
\hline
\end{tabular}

Berdasarkan tabel di atas diketahui bahwa dari 72 orang tenaga kesehatan 24 Orang (40\%) menyatakan pengaruh sosial kurang mendukung dalam menggunakan SIMRS dan 48 Orang (60\%) menyatakan pengaruh sosial mendukung dalam menggunakan SIMRS.

Tabel 8. Distribusi Frekuensi Data Univariat Responden berdasarkan Kondisi Pemfasilitas

\begin{tabular}{ccc}
\hline Kondisi pemfasilitas & Frekuensi & Persentase (\%) \\
\hline Kurang mendukung & 29 & 41 \\
Mendukung & 43 & 59 \\
\hline Total & 72 & 100 \\
\hline
\end{tabular}


Berdasarkan tabel di atas diketahui bahwa dari 72 orang tenaga kesehatan 29 Orang (41\%) menyatakan kondisi pemfasilitas kurang baik dalam penggunaan SIMRS dan 43 Orang (59\%) kondisi pemfasilitas baik dalam penggunaan SIMRS.

Tabel 9. Distribusi Frekuensi Data Univariat Responden berdasarkan Pemanfaatan SIMRS

\begin{tabular}{ccc}
\hline Pengaruh sosial & Frekuensi & Persentase (\%) \\
\hline Kurang baik & 25 & 35 \\
Baik & 47 & 65 \\
\hline Total & 72 & 100 \\
\hline
\end{tabular}

Berdasarkan tabel di atas diketahui bahwa dari 72 orang tenaga kesehatan sebanyak 25 Orang (35\%) menyatakan kurang baik dalam pemanfaatan SIMRS dan 47 orang (65\%) menyatakan baik dalam pemanfaatan SIMRS dan 48 Orang $(60 \%)$.

\section{Analisa Bivariat}

Tabel 10. Tabulasi Silang Ekspektasi Usaha dengan Pemanfaatan SIMRS

\begin{tabular}{|c|c|c|c|c|c|c|c|c|}
\hline \multirow{3}{*}{$\begin{array}{c}\text { Ekspektasi } \\
\text { Usaha }\end{array}$} & \multicolumn{6}{|c|}{ Pemanfaatan SIMRS } & \multirow{3}{*}{$\begin{array}{c}p \\
\text { Value }\end{array}$} & \multirow{3}{*}{ PR CI 95\% } \\
\hline & \multicolumn{2}{|c|}{ Cukup baik } & \multicolumn{2}{|c|}{ Baik } & \multicolumn{2}{|c|}{ Jumlah } & & \\
\hline & $f$ & $\%$ & $f$ & $\%$ & $f$ & $\%$ & & \\
\hline Kurang baik & 15 & 20,8 & 10 & 13,9 & 25 & 34,7 & \multirow{3}{*}{0.002} & \multirow{3}{*}{$\begin{array}{c}2,820 \\
(1,4935,328)\end{array}$} \\
\hline Baik & 10 & 13,9 & 37 & 51,4 & 47 & 65,3 & & \\
\hline Jumlah & 25 & 34,7 & 47 & 65,3 & 72 & 100 & & \\
\hline
\end{tabular}

Berdasarkan hasil uji statistik pada ekspektasi usaha dengan pemanfaatan SIMRS diketahui bahwa dari 72 responden yang menyatakan ekpekstasi usaha kurang memiliki mempuyai pemanfaatan SIMRS yang cukup baik sebanyak 15 orang
$(20,8 \%)$ dan yang menyatakan ekspektasi usaha kurang baik mempuyai pemanfaatan SIMRS yang baik sebanyak 10 orang (13,9\%). Sedangkan responden yang menyatakan ekspektasi baik mempunyai pemanfaatan SIMRS yang cukup baik sebanyak 10 orang $(13,9 \%)$ dan yang menyatakan ekspektasi usaha baik memiliki pemanfaatan SIMRS yang baik sebanyak 37 orang $(51,4 \%)$ dengan nilai $P=0.002$ dan dengan nilai proporsi rasio sebesar 2,820, yang artinya ekspetasi usaha memiliki peluang 2,820 kali lebih besar dalam pemanfataan Sistem Informasi Manajemen Rumah sakit.

Hasil analisis penelitian ini menunjukkan adanya kesamaan dengan penelitian yang dilakukan oleh Fatimatus (2016). Ada hubungan negatif antara ekspektasi usaha dengan minat perilaku pengguna untuk menggunakan SIM di Rumah Sakit Paru Jember. Nilai negatif menunjukkan bahwa responden tidak membutuhkan usaha yang besar saat menggunakan SIM karena sistem yang digunakan mudah sehingga meningkatkan minat pengguna untuk menggunakan SIM. Hasil penellitian dari Hamzah (2010) yang menyatakan bahwa ekspektasi usaha berpengaruh signifikan terhadap pemanfaatan sistem informasi. Hasil penelitian ini juga sejalan dengan hasil penelitian yang dilakukan oleh Hasyim (2010), dan Rosita (2013) tentang pengaruh ekspektasi usaha terhadap penggunaan sistem informasi akuntansi dilakukan yang menunjukkan bahwa ekspektasi (harapan) usaha memiliki pengaruh positif terhadap penggunaan sistem 
informasi akuntansi. Sehingga semakin tinggi ekspektasi usaha maka semakin tinggi penggunaan sistem informasi akuntansi.

Tabel 11. Tabulasi Silang Ekspektasi Kinerja dengan Pemanfaatan SIMRS

\begin{tabular}{|c|c|c|c|c|c|c|c|c|}
\hline \multirow{3}{*}{$\begin{array}{c}\text { Ekspektasi } \\
\text { Usaha }\end{array}$} & \multicolumn{6}{|c|}{ Pemanfaatan SIMRS } & \multirow{3}{*}{$\begin{array}{c}P \\
\text { Value }\end{array}$} & \multirow{3}{*}{ PRCl 95\% } \\
\hline & \multicolumn{2}{|c|}{ Cukup baik } & \multicolumn{2}{|c|}{ Baik } & \multicolumn{2}{|c|}{ Jumlah } & & \\
\hline & $f$ & $\%$ & $f$ & $\%$ & $f$ & $\%$ & & \\
\hline Kurang baik & 15 & 20,8 & 10 & 15,3 & 26 & 36,1 & \multirow{3}{*}{0,004} & \multirow{3}{*}{$\begin{array}{c}2.654 \\
(1,400-5,031)\end{array}$} \\
\hline Baik & 10 & 13,9 & 36 & 50,0 & 46 & 63,9 & & \\
\hline Jumlah & 26 & 36,1 & 46 & 65,3 & 72 & 100 & & \\
\hline
\end{tabular}

Berdasarkan tabel di atas diketahui bahwa hasil uji statistik pada ekspektasi kinerja dengan pemanfaatan SIMRS, diketahui bahwa dari 72 responden yang menyatakan ekpekstasi kinerja kurang baik memiliki pemanfaatan SIMRS yang cukup baik sebanyak 15 orang $(20,8 \%)$ dan yang menyatakan ekspektasi kinerja kurang baik memliki pemanfaatan SIMRS yang baik sebanyak 10 orang (13,9\%). Sedangkan responden yang menyatakan ekspektasi kinerja baik memiliki pemanfaatan SIMRS yang cukup baik sebanyak 10 orang $(15,3 \%)$ dan yang menyatakan ekspektasi kinerja kurang baik memiliki pemanfaatan SIMRS yang baik sebanyak 36 orang $(50,0 \%)$ dengan nilai $P=0.004$ dan dengan nilai proporsi rasio sebesar 2,654, yang artinya ekspetasi kinerja memiliki peluang 2,654 kali lebih besar dalam pemanfataan Sistem Informasi Manajemen Rumah sakit.

Beberapa hasil penelitian yang mendukung tentang pengaruh ekspektasi kinerja terhadap penggunaan sistem informasi akuntansi dilakukan oleh Hasyim (2010), dan Rosita (2013) menunjukkan bahwa ekspektasi (harapan) kinerja memiliki pengaruh positif terhadap penggunaan sistem informasi akuntansi. Sehingga semakin tinggi ekspektasi kinerja maka semakin tinggi penggunaan sistem informasi akuntansi. Dapat disimpulkan bahwa untuk dapat meningkatkan minat Tenaga kesehatan dalam penggunaan SIMRS maka seseorang harus yakin dan percaya bahwa dengan menggunakan SIMRS dapat meningkatkan kinerja.

Tabel 12. Tabulasi Silang Pengaruh Sosial dengan Pemanfaatan SIMRS

\begin{tabular}{|c|c|c|c|c|c|c|c|c|}
\hline \multirow{3}{*}{$\begin{array}{l}\text { Pengaruh } \\
\text { Sosial }\end{array}$} & \multicolumn{6}{|c|}{ Pemanfaatan SIMRS } & \multirow{3}{*}{$\begin{array}{c}P \\
\text { Value }\end{array}$} & \multirow{3}{*}{ PR Cl 95\% } \\
\hline & \multicolumn{2}{|c|}{ Cukup baik } & \multicolumn{2}{|c|}{ Baik } & \multicolumn{2}{|c|}{ Jumlah } & & \\
\hline & $f$ & $\%$ & $f$ & $\%$ & $f$ & $\%$ & & \\
\hline Kurang baikk & 13 & 18,1 & 11 & 15,3 & 24 & 33,3 & \multirow{3}{*}{0,019} & \multirow{3}{*}{$\begin{array}{c}2,167 \\
(1,174-3,999)\end{array}$} \\
\hline baik & 12 & 16,7 & 36 & 50,0 & 48 & 66,7 & & \\
\hline Jumlah & 26 & 36,1 & 46 & 65,3 & 72 & 100 & & \\
\hline
\end{tabular}

Berdasarkan tabel di atas diketahui hasil uji statistik pada pengaruh sosial dengan pemanfaatan SIMRS, diketahui bahwa dari 72 responden yang menyatakan pengaruh sosial kurang baik memiliki pemanfaatan SIMRS yang cukup baik sebanyak 13 orang $(18,1 \%)$ dan yang menyatakan pengaruh sosoial kurang baik memiliki pemanfaatan SIMRS yang baik sebanyak 12 orang $(16,7 \%)$. Sedangkan responden yang menyatakan pengaruh sosial yang baik memiliki pemanfaatan SIMRS yang cukup baik sebanyak 11 orang $(15,3 \%)$ dan yang menyatakan pengaruh sosial baik memiliki pemanfaatan SIMRS yang baik sebanyak 36 orang $(50,0 \%)$ dengan nilai $P=0.019$, dan dengan nilai proporsi rasio sebesar 2,167, yang artinya pengaruh sosial memiliki peluang 2,167 kali lebih besar dalam 
pemanfataan Sistem Informasi Manajemen Rumah sakit.

Beberapa hasil penelitian yang mendukung tentang pengaruh faktor sosial terhadap penggunaan sistem informasi dilakukan oleh Hasyim (2010), dan Rosita (2013) menunjukkan bahwa faktor sosial berpengaruh positif terhadap penggunaan sistem informasi akuntansi. Sehingga semakin tinggi faktor sosial maka semakin tinggi penggunaan sistem informasi akuntansi.

Tabel 13. Tabulasi Silang Kondisi Pemfasilitas Dengan Pemanfaatan SIMRS

\begin{tabular}{|c|c|c|c|c|c|c|c|c|}
\hline \multirow{3}{*}{$\begin{array}{c}\text { Kondisi } \\
\text { pemfasilitas }\end{array}$} & \multicolumn{6}{|c|}{ Pemanfaatan SIMRS } & \multirow{3}{*}{$\begin{array}{c}P \\
\text { Value }\end{array}$} & \multirow{3}{*}{$P R C l 95 \%$} \\
\hline & \multicolumn{2}{|c|}{ Cukup baik } & \multicolumn{2}{|c|}{ Baik } & \multicolumn{2}{|c|}{ Jumlah } & & \\
\hline & $f$ & $\%$ & $f$ & $\%$ & $f$ & $\%$ & & \\
\hline \multirow{2}{*}{$\begin{array}{c}\text { Kurang } \\
\text { Mendukung } \\
\text { mendukung }\end{array}$} & 17 & 23,6 & 12 & 16,7 & 29 & 40,3 & \multirow{3}{*}{0,001} & \multirow{3}{*}{$\begin{array}{c}3,151 \\
(1,571-3,519)\end{array}$} \\
\hline & 8 & 11,1 & 35 & 48,6 & 43 & 59,7 & & \\
\hline Jumlah & 26 & 44,7 & 46 & 65,3 & 72 & 100 & & \\
\hline
\end{tabular}

Berdasarkan tabel di atas diketahui hasil uji statistik pada kondisi pemfasilitas dengan pemanfaatan SIMRS, diketahui bahwa dari 72 responden yang menyatakan kondisi pemfasilitas kurang mendukung memiliki pemanfaatan SIMRS yang cukup baik sebanyak 17 orang $(23,6 \%)$ dan yang menyatakan kondisi pemfasilitas kurang mendukung memiliki pemanfaatan SIMRS yang baik sebanyak 12 orang $(16,7 \%)$. Sedangkan responden yang menyatakan kondisi pemfasilitas yang mendukung memiliki pemanfaatan SIMRS yang cukup baik sebanyak 8 Orang $(11,1 \%)$ dan yang menyatakan kondisi pemfasilitas mendukung memiliki pemanfaatan SIMRS yang baik sebanyak 35 orang $(48,6 \%)$ dengan nilai $P=0.019$. dan dengan nilai proporsi rasio sebesar 3,151, yang artinya kondisi pemfasilitas memiliki peluang 3,151 kali lebih besar dalam pemanfataan Sistem Informasi Manajemen Rumah sakit.

Tabel 14. hasil logistic regression Tahap Terakhir Faktor-Faktor Yang Berhubungan Dengan Pemanfaatan SIMRS

\begin{tabular}{|c|c|c|c|c|c|c|c|}
\hline \multirow{2}{*}{ Variabel } & \multirow{2}{*}{ B } & \multirow[b]{2}{*}{ S.E } & \multirow[b]{2}{*}{ Wald } & \multirow{2}{*}{ Pvalue } & \multirow{2}{*}{$\operatorname{Exp}(B)$} & \multicolumn{2}{|c|}{$\mathrm{Cl} 95 \%$} \\
\hline & & & & & & Lower & Upper \\
\hline Ekspektasi & & & & & & & \\
\hline Usaha* & 1.312 & 0.524 & 6.273 & 0,01 & 3,712 & 1.330 & 10.361 \\
\hline
\end{tabular}

Berdasarkan hasil uji statistik Logistic Regression diketahui bahwa Dari hasil tersebut yang paling memiliki hubungan dengan Pemanfatan SIMRS di Rumah Sakit Umum Sembiring Tahun 2020 adalah variabel ekspektasi usaha dengan nilai $P=0.012$ dan Exp (B) 3,712 dengan $C I$ 95\%, yang artinya tenaga kesehatan yang memiliki ekspektasi usaha yang baik lebih bepeluang 3,712 kali dalam memanfaatkan SIMRS dibandingkan dengan tenaga kesehatan yang memiliki ekspetasi usaha yang kurang baik.

Hasil penelitian ini sejalan dengan penelitian dari Setiawan (2019), yang menyatakan bahwa ekspektasi usaha memiliki hubungan yang paling kuat dengan penggunaan sistem akutansi, dibandingkan dengan ekspektasi kinerja, pengaruh sosial, dan kondisi pemfasilitas. Artinya seseorang akan menggunakan suatu sistem akan dapat mengurangi upaya dan tenaga dalam penggunaanya. 


\section{KESIMPULAN}

Berdasarkan hasil penelitian dan pembahasan yang telah diuraikan sebelumnya dapat diambil kesimpulan sebagai berikut:

1. Hasil penelitian menunjukan, adanya hubungan antara Ekspektasi usaha dengan pemanfatan SIMRS di rumah sakit umum Sembiring

2. Hasil penelitian menunjukan, adanya hubungan antara Ekspektasi Kinerja dengan pemanfatan SIMRS di rumah sakit umum Sembiring

3. Hasil penelitian menunjukan, adanya hubungan antara pengaruh sosial dengan pemanfatan SIMRS di rumah sakit umum Sembiring

4. Hasil penelitian menunjukan, adanya hubungan antara kondisi pemfasilitas dengan pemanfatan SIMRS di rumah sakit umum Sembiring.

5. Hasil penelitian menunjukan, variabel yang paling berhubungan dengan pemanfatan SIMRS di rumah sakit umum Sembiring adalah ekspektasi usaha

\section{DAFTAR PUSTAKA}

Arikunto, Suharsimi. (2010). Prosedur Penelitian : Suatu Pendekatan Praktis, edisi revisi 2010. Jakarta : Rineka Cipta

Fatimatus, Zainiyah 2016. Analisis Faktor Yang Berhubungan Dengan Perilaku Penggunaan Sistem Informasi Manajemen Di
Rumah Sakit Paru

Jember. Universitas Jember

Permenkes RI no 1171 tahun 2011 tentang Sistem Informasi Rumah Sakit

Permenkes RI no 822013 tentang Sistem Informasi manajemen rumah sakit

Rustiyanto, E. 2011. Sistem Informasi Manajemen Rumah Sakit yang Terintegrasi. Yogyakarta: Gosyen Publishing

Syafara, 2009. Pelaksanan SIMRS DI Rumah Sakit Pringadi Medan tahun 2009, Universitas

Sumatera Utara. Terhadap Kinerja Instansi Pemerintah (Studi Pada Satuan Kerja Perangkat Daerah Kabupaten Kampar).

Undang-undang RI no. 36 tahun 2009 tentang Kesehatan Jakarta

Undang-undang RI no. 36 tahun 2014 tentang tenaga Kesehatan Jakarta

Undang-undang RI no. 44 tahun 2009 Tentang Rumah Sakit Jakarta

Venkatesh, V., James Y. L. Thong., \& Xin Xu. 2012. Consumer Acceptance and Use of Information Technology: Extending The Unified Theory of Acceptance and Use of Technology. MIS Quarterly: Hongkong. 